\title{
Evaluasi Perubahan Kebugaran Kardiorespirasi Pada Lansia Selama Intervensi Pijat Refleksi dengan Senam Lansia 5 Minggu
}

\author{
Imam Waluyo, Hafnah Rosyita, Slamet Sumarno \\ Universitas Binawan \\ imamwaluyo@gmail.com
}

\begin{abstract}
Abstrak
Tujuan : Penelitian ini bertujuan untuk mengetahui dimana perubahan terjadi pada system kardiovaskular selama pemberian senam dan refleksi berlangsung Bahan dan Cara : Penelitian dilakukan Penelitian ini menggunakan design quasi experimental design dengan rancangan pre dan post pada kelompok lansia $\geq 60$ tahun. Pada penelitian ini lansia dilakukan pemeriksaan uji jarak tempuh berjalan 6 menit (6MWT) sebelum dilakukannya sesi intervensi, kemudian dipantau dan di evaluasi saat intervensi berlangsung pada pertemuan ke-8 dan ke-10 kemudian pemeriksaan dilakukan kembali setlah peermuan ke10. Intervensi di mulai dengan terapi pijat refleksi kemudian dilanjutkan dengan senam lansia untuk melihat perubahan uji jarak tempuh berjalan 6 menit. Dengan jumlah subyek 20 orang dan selama intervensi 5 minggu mengalami drop out 15 orang. Hasil : Berdasarkan subjek penelitian didapatkan sebelum intervensi subjek yang memiliki jarak tempuh 6 menit baik sebanyak 3 orang (20\%), Sesudah intervensi subjek yang memiliki jarak tempuh 6 menit baik sebanyak 11 orang $(73,3 \%)$. Peningkatan daya tahan Nampak pada minggu kedua . Banyak faktor yang mempengaruhi peningkatan daya tahan Kesimpulan terdapat Perubahan Kebugaran Kardiorespirasi Pada Lansia Selama Intervensi Pijat Refleksi dengan Senam Lansia 5 Minggu terutama Nampak pada minggu kedua
\end{abstract}

Kata kunci : Kebugaran kardiorespirasi , Pijat Refleksi, senam lansia 


\begin{abstract}
Objective: This study aims to determine where changes occur in the cardiovascular system during exercise and reflection take place. Materials and Methods: The study was conducted. This study used a quasi-experimental design with pre and post designs in the elderly group 60 years. In this study, the elderly were tested for walking distance test for 6 minutes (6MWT) before the intervention session, then monitored and evaluated when the intervention took place at the 8th and 10th meetings, then the examination was carried out again after the 10th meeting. The intervention started with reflexology therapy and then continued with elderly exercise to see changes in the 6-minute walking distance test. With the number of subjects 20 people and during the 5-week intervention experienced a drop out of 15 people. Results: Based on the research subjects, it was found that before the intervention, the subjects who had a good 6-minute mileage were as many as 3 people (20\%), after the intervention, the subjects who had a good 6-minute mileage were 11 people $(73.3 \%)$. Increased endurance is seen in the second week. Many factors affect the increase in endurance. Conclusions there are changes in cardiorespiratory fitness in the elderly during the reflexology intervention with 5-week elderly exercise, especially in the second week
\end{abstract}

Keywords: cardiorespiratory fitness, reflexology, elderly exercise 


\section{Pendahuluan}

Lansia mengalami perubahan pada metabolisme energi karena lansia mengalami ganguaan nafsu makan dan menjadi mudah kenyang, hal ini dikarenakan lansia sudah mengalami penurunan sensitifitas insulin dan gangguan indera pengecap dan pembau (Roberts dan Rosenberg, 2006). Lansia juga cenderung mengalami penurunan masa otot dan peningkatan masa lemak (Wu et al., 2016). Hal ini juga menyebabkan lansia mengalami gangguan fungsional (Orsi, Xavier, dan Ramos, 2011), keseimbangan (Downs, Marquez, dan Chiarelli, 2014), gangguan tidur (Livingston, Blizard, dan Mann, 1993). Pada lansia penurunan aktifitas juga dapat mempengaruhi kualitas hidup mereka (Gerber, Botes, Mostert, Vorster, dan Buskens, 2016).

Di setiap negara, proporsi orang yang berusia di atas 60 tahun tumbuh lebih cepat dari kelompok usia lainnya, Perserikatan Bangsa Bangsa (PBB) setuju batas ambang adalah lebih dari 60 tahun untuk merujuk pada populasi lansia. Lanjut Usia adalah seseorang yang mencapai usia 60 tahun ke atas, berdasarkan Undang Undang Nomor 13 Tahun 1998 tentang Kesejahteraan Lanjut Usia. Lansia dibagi kedalam tiga pengelompokan sesuai dengan umur yaitu: young old $(65-74)$, middle old (75 - 84) dan oldest old (85 keatas) (Zizza, Ellison, dan Wernette, 2009). Indonesia termasuk negara berstruktur tua, berdasarkan hasil Susenas tahun 2014, jumlah Lansia di Indonesia mencapai 20,24 juta orang atau sekitar 8,03\% dari seluruh penduduk Indonesia. Proporsi penduduk lansia di Indonesia pada tahun 2012 sebesar 7,59\%. Dengan jumlah lansia perempuan (10.046.073 jiwa atau 54\%) lebih banyak dari pada lansia laki - laki (8.538.832 jiwa atau 46\%). Pada tahun 2000 - 2005 Usia Harapan Hidup (UHH) di Indonesia mencapai usia $68,1 \%$ tahun, sedikit lebih tinggi dari UHH rata - rata dunia.

Studi sebelumnya menunjukkan bahwa penuaan melibatkan penurunan fungsi kardiovaskular (yang disebutkan oleh Fleg, et al., 1990;.Gerstenblith et al. 1987; Higginbotham dkk. 1986; Hossack \& Bruce 1982; Konishi dkk. 1990; Nixon Et al. 1985 dalam Green \& Crouse, 1993). ${ }^{15}$ Proses penuaan melibatkan perubahan struktur kardiovaskular dan fisiologi yang termasuk peningkatan endapan amiloid, basofilik, lipid, dan zat jenis kolagen (Disebutkan oleh Klausner dan Schwartz 1985 dalam 
Green \& Crouse, 1993), ${ }^{15}$ dan myosit dan perubahan jaringan connective (Disebutkan oleh Pomerance 1975 dalam Green \& Crouse, 1993). ${ }^{15}$ Ada bukti yang menghubungkan temuan ini dengan kelainan jantung yang serius (Disebutkan oleh Olsen et al. 1987 dalam Green \& Crouse, 1993). ${ }^{15}$ Perubahan yang sangat merugikan seperti penurunan respons reseptor adrenergik, arterial distensibilitas, dan kepatuhan ventrikel berkontribusi pada peningkatan tekanan arteri, vaskular resistensi dan afterload, hipertrofi ventrikel,aserta fungsi kontraksi ventrikel yang berkurang (disebutkan oleh Lakatta 1990 dalam Green \& Crouse, 1993). ${ }^{15}$

Dalam populasi secara umum, kebugaran kardiorespirasi (kondisis fungsional kinerja jantung paru untuk dapat bekerja dengan baik dalam sistem sirkulasi dan pernafasan untuk aktivitas fisik secara berkelanjutan) sangat kuat dan merupakan prediktor independent terhadap penyakit kardiovaskular dengan relatif resiko $(\mathrm{RR})=1.56$; $95 \%$ confidence interval $(\mathrm{CI})=$ 1.39-1.75; $\mathrm{p}<0.001]$ dan segala penyebab kematian $(\mathrm{RR}=1.70$; $95 \% \mathrm{CI}=1.51-1.92 ;<0.001)$

(Disebutkan oleh Kodama et al., 2009 dalam Vancampfort, et al., 2017). ${ }^{16}$

Rendahnya kebugaran kardiorespirasi merupakan faktor terjadinya resiko segala penyebab kematian terkait kardiovaskular, dengan begitu kebugaran kardiorespirasi yang baik berhubungan positif dengan rendahnya resiko segala penyebab kematian karena penyakit kardiovaskular (Ehrman, et al., 2017). ${ }^{17}$ Data suatu penelitian pun membuktikan bahwa tingkat kebugaran kardiorespirasi yang tinggi berkaitan dengan menurunnya resiko kejadian diabetes dengan faktor demografi serta faktor resiko lainnya yang mendasarinya (Juraschek, et al., 2015). ${ }^{18}$ Pada orang yang di berikan intervensi untuk manajemen resiko kardiovaskular dan penyakit kardiorespirasi yang komprehensif dapat meningkatkan kesehatan dan keselamatan (Li, Lipsey, Leach \& Nelson, 2017). ${ }^{19}$ Kebugaran kardiorespirasi dapat dimanfaatkan sebagai indikator 
risiko kardiovaskular pada populasi lanjut usia. Kebugaran kardiorespirasi yang lebih tinggi dapat ditunjukkan dengan uji coba enam menit atau 6 minutes walking test (6MWT) (Rômulo, et al., 2012). ${ }^{7}$

Kapasitas berjalan merupakan faktor kualitas hidup pada orang dengan penyakit jantung (Gayda,et al.,2004). ${ }^{20}$ Jarak ambulasi ditunjukkan sehubungan dengan konsumsi oksigen dengan gejala maksimal (Gayda,et al.,2004). ${ }^{20}$ Rendahnya kapasitas kardiopulmonal dan lemahnya otot skeletal berkaitan dengan rendahnya performa dalam 6MWT (Keyser, et al., 2015). ${ }^{21}$ Kinerja buruk pada tungkai bawah merupakan prediktor perkembangan kerugian fungsional. Studi lain menunjukkan adanya hubungan antara kecepatan berjalan dan kekuatan otot pada tungkai bawah (Roma, et al., 2013). ${ }^{10}$ Secara umum, laki-laki memiliki 6 minutes walked distance (6MWD) lebih tinggi daripada wanita, efek signifikan ketinggian pada 6MWD dikaitkan dengan langkah yang lebih panjang pada individu yang lebih tinggi. Panjang stride adalah salah satu faktor penentu kecepatan berjalan yang paling utama dan obesitas meningkatkan beban kerja untuk intensitas latihan tertentu, sehingga mengurangi 6MWD (Joobeur, et al., 2016). ${ }^{22}$

Beberapa penelitian telah mengevaluasi keuntungan yang dicapai dengan latihan kekuatan otot setelah latihan senam lansia dan penguatan bersamaan. Untuk mengamati peningkatan kekuatan otot serta pengurangan persentase lemak dan peningkatan tingkat lipoprotein densitas tinggi pada pria dan wanita lanjut usia setelah berpartisipasi dalam program latihan senam lansia yang diselingi latihan penguatan otot (Lustosa et al., 2015). Salah satu terapi pelengkap yang paling popular ini telah didefinisikan sebagai sistem diagnosis dan pengobatan China dan India yang berasal dari tahun 3000 SM adalah refleksologi. Berdasarkan kepercayaan bahwa seluruh tubuh diwakili di kaki (kebanyakan di telapak kaki), dan organ dalam dapat dirangsang dengan menekan area tertentu pada 
kaki (kurang umumnya tangan) . Penulis lain telah menjelaskan "Refleks" dalam konteks 'refleksologi' berarti 'refleksi' semua organ, sistem dan struktur tubuh ke kaki atau tangan (Ernst, 2009).

Pada penelitian (Magistro, Liubicich, Candela, dan Ciairano, 2013) disimpulkan bahwa latihan dapat mempengaruhi jarak tempuh 6 menit dengan bukti bahwa kelompok intervensi menunjukkan perbaikan yang signifikan berkenaan dengan jarak tempuh 6 menit. Selanjutnya percobaan lain menguji apakah latihan berpengaruh terhadap uji jarak tempuh dan terbukti bahwa jarak tempuh meningkat dalam kelompok latihan dengan jarak dari $33 \mathrm{~m}$ sampai $46 \mathrm{~m}$ (Manfredini et al., 2016). Penelitian ini bertujuan untuk mengetahui dimana perubahan terjadi pada system kardiovaskular selama pemberian senam dan refleksi berlangsung

Metode

Penelitian ini menggunakan design quasi experimental design dengan rancangan pre dan post pada kelompok lansia $\geq 60$ tahun. Pada penelitian ini lansia dilakukan pemeriksaan uji jarak tempuh berjalan 6 menit (6MWT) sebelum dilakukannya sesi intervensi, kemudian dipantau dan di evaluasi saat intervensi berlangsung pada pertemuan ke-8 dan ke-10 kemudian pemeriksaan dilakukan kembali setlah peermuan ke-10. Intervensi di mulai dengan terapi pijat refleksi kemudian dilanjutkan dengan senam lansia untuk melihat perubahan uji jarak tempuh berjalan 6 menit.

$$
\mathrm{Sp}^{2}=\frac{\begin{array}{c}
{\left[\left(\mathrm{n}_{1}-1\right) \mathrm{S}_{1}{ }^{2}+\left(\mathrm{n}^{2}-1\right) \mathrm{S}_{2}{ }^{2}\right]} \\
\left(\mathrm{n}_{1}-1\right)+\left(\mathrm{n}_{2}-1\right)
\end{array}}{\left.-{ }^{2}\right)}
$$

Keterangan :

- $\mathrm{Z} 1-\alpha / 2=$ Derajat kemaknaan sebesar $5 \%$

- $\quad Z 1-\beta=$ Derajat kekuatan uji sebesar $80 \%$ 
- $\mu 1=$ rata-rata skor setelah intervensi (Jurnal $1=$ Sun., et al, 2010).

- $\mu 2=$ rata-rata skor setelah intervensi (Jurnal 2 = Fragoso., et al, 2015).
Sample sebanyak 20 responden dengan Kriteria drop out bila tidak mengikuti latihan sebanyak $3 \mathrm{x}$ selama intervensi

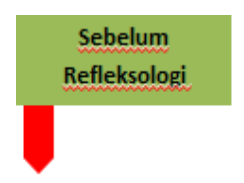

3 4 5 6 7 8
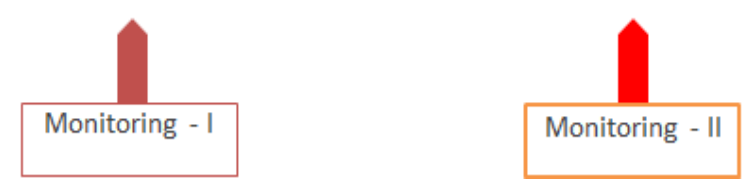

\section{HASIL PENELITIAN}

Terdapat 5 subyek yang drop out sehingga jumlah yang dilakukan analisis sebanyak 15 orang dengan deskripsi dalam table 1

Tabel 1 Tabel Distribusi Karakteristik Subjek Penelitian ( $\mathrm{n}=15)$

\begin{tabular}{lllll}
\hline Karakteristik Subjek & Rata-rata \pm SD & Min & Max & Cl 95\% \\
\hline $\begin{array}{l}\text { Usia } \\
\text { Laki-laki }\end{array}$ & $65,4 \pm 5,345$ & 60 & 72 & $62,9-67,9$ \\
$\quad$ Perempuan & $64,88 \pm 5,643$ & 60 & 72 & $60,16-69,59$ \\
Jarak Tempuh Jalan 6 & $65,75 \pm 5,362$ & 60 & 72 & $62,34-69,16$ \\
Menit (6 MWD & $372 \pm 13,94$ & $355 \mathrm{~m}$ & $398 \mathrm{~m}$ & $365,2-380,6$ \\
$\quad$ Sebelum Intervensi & $374 \pm 13,42$ & $350 \mathrm{~m}$ & $390 \mathrm{~m}$ & $367,2-382,1$ \\
$\quad$ Monev-I & $393 \pm 16,32$ & $336 \mathrm{~m}$ & $480 \mathrm{~m}$ & $373,2-413,4$ \\
$\quad$ Monev-II & $412 \pm 17,09$ & $395 \mathrm{~m}$ & $460 \mathrm{~m}$ & $402,8-421,8$ \\
\hline Sesudah Intervensi & & & & \\
\hline
\end{tabular}

Rata - rata jarak tempuh 6 menit sebelum intervensi adalah $372 m \pm 13.9$ dengan http://ejournal.urindo.ac.id/index.php/TI 
taraf kepercayaan $95 \%$ (CI

95\%) 365.2 - 380.6, monev-I 374m

$\pm 13,42$ dengan taraf kepercayaan 95\% 367.2-382.1, monev-II dengan rata-rata $393 \mathrm{~m} \pm 16.3$ dengan taraf kepercayaan 95\% 373.2-413.4 dan rata - rata jarak tempuh 6 menit sesudah intervensi $\quad 412 \mathrm{~m} \pm 17.1$ dengan taraf kepercayaan 95\% (CI 95\%) antara 402.8-421.8, Untuk melihat distribusi frekuensi dalam penelitian ini, maka digunakan beberapa literature sebagai pedoman, diantaranya :
1. $350-380 \mathrm{~m}$ (Lemah), menurut Cardiopulmonary Physical Therapy Journal (APTA, 2010).

2. $380-400 \mathrm{~m}$ dan $>400 \mathrm{~m}$ (Normal dan Kuat), menurut Six-minute walk distance in healthy Singaporean adults cannot be predicted using reference equations derived from Caucasian populations (Hermione et al., 2006).

Bagan 5.1 Distribusi Frekuensi

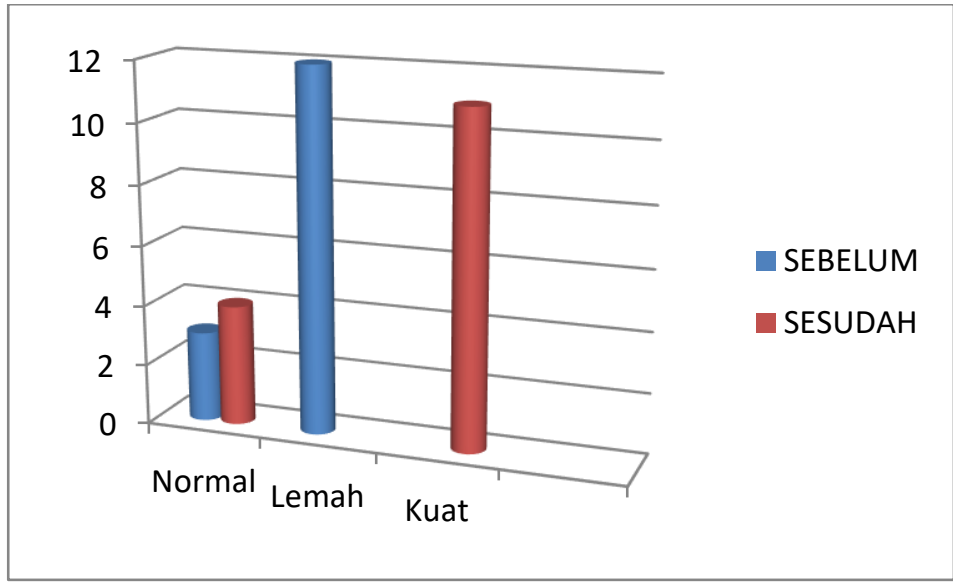

Berdasarkan subjek penelitian didapatkan sebelum intervensi subjek yang memiliki jarak tempuh 6 menit baik sebanyak
3 orang (20\%), Sesudah intervensi subjek yang memiliki jarak tempuh 6 menit baik sebanyak 11 orang $(73,3 \%)$.

Tabel 2 Normalitas rata - rata sebelum dan sesudah intervensi senam lansia dan refleksologi $(\mathrm{n}=15)$

\begin{tabular}{ccc}
\hline Jarak Tempuh 6 Menit & Hasil Uji Normalitas & Keterangan \\
\hline Sebelum Intervensi & 0,200 & Distribusi normal \\
\hline
\end{tabular}




\begin{tabular}{lcc}
\hline Monev-I & 0,200 & Distribusi normal \\
Monev-II & 0,200 & Distribusi normal \\
Sesudah Intervensi & 0,022 & Distribusi Tidak Normal \\
\hline
\end{tabular}

Pada tabel 2 diatas dapat dilihat dari tabel uji normalitas Kolmogrov-Smirnov, terdapat pada nilai 0.200 sebelum intervensi yang menyatakan data berdistribusi normal, kemudian nilai 0.200 pada pemantauan Minggu ke-II atau Monev-I yang menyatakan data berdistribusi normal, dilanjutkan dengan nilai 0.200 pada pemantauan Minggu ke-IV atau monev-II nilai ini menunjukkan data berdistribusi normal dan 0.022 setelah berakhirnya masa intervensi dengan hasil tersebut menunjukkan data berdistribusi tidak normal. Hasil diatas menyatakan bahwa nilai distribusi normal pada sebelum intervensi,monev-I,monev-II dan berdistribusi tidak normal pada sesudah itervensi. Dikarenakan data sebelum intervensi dengan monev-I dan monev-I dengan monev-II berdistribus normal dan normal maka uji analisis menggunakan uji Paired T-test. Sedangkan, pada data monev-II dengan sesudah intervensi menggunakan uji Wilcoxon test dikarenakan berditribusi norma dan tidak normal.

Tabel .3

Perubahan Jarak Tempuh 6 Menit sebelum dan sesudah intervensi

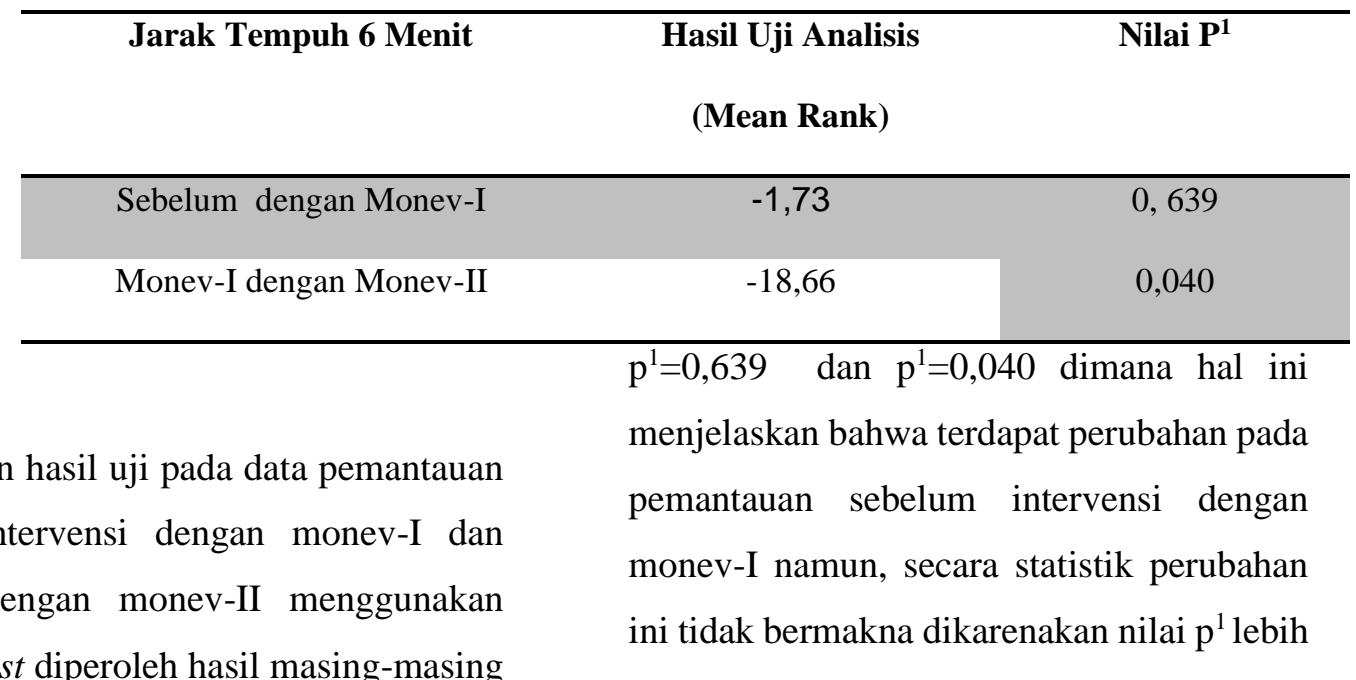

Berdasarkan hasil uji pada data pemantauan sebelum intervensi dengan monev-I dan monev-I dengan monev-II menggunakan Paired T-test diperoleh hasil masing-masing http://ejournal.urindo.ac.id/index.php/TI 
besar dari 0,005. Sedangkan, monev-I dengan monev-II diperoleh nilai $\mathrm{p}^{1}=0,040$ yang menggambarkan adanya perubahan pada sesi ini dengan hasil uji statistic yang bermakna

Tabel 4 Perubahan Jarak Tempuh 6 Menit sebelum dan sesudah intervensi

\begin{tabular}{ccc}
\hline Jarak & $\begin{array}{c}\text { Hasil Uji Analisis } \\
(\text { Mean Rank) }\end{array}$ & Nilai P \\
\hline $\begin{array}{c}\text { Monev-I dengan } \\
\text { sesudah }\end{array}$ & $\mathbf{5 , 0 0}$ & 0,02 \\
\hline $\begin{array}{l}\text { Menurun (4) } \\
\text { Meningkat (11) } \\
\text { Tetap(0) }\end{array}$ & 9,09 & \\
\hline
\end{tabular}

Hasil Uji Wilcoxon , 11 subjek jarak tempuh 6 menit meningkat, 4 subjek jarak tempuh 6 menit menurun, dan 0 subjek tetap. Secara statistik menunjukkan perbedaan yang bermakna $\mathrm{p}=0,02($ $\mathrm{p}<0,05)$ sehingga $\mathrm{H}_{0}$ di tolak dan $\mathrm{H}_{\mathrm{a}}$ diterima hal ini menandakan adanya perubahan jarak tempuh 6 menit selama intervensi kombinasi terapi 5 Minggu.

Adapun gambaran perubahan dari setiap sesi pemantauan selama pemberian program intervensi kombinasi terapi 5 Minggu dapat digambarkan dengan garfik berikut

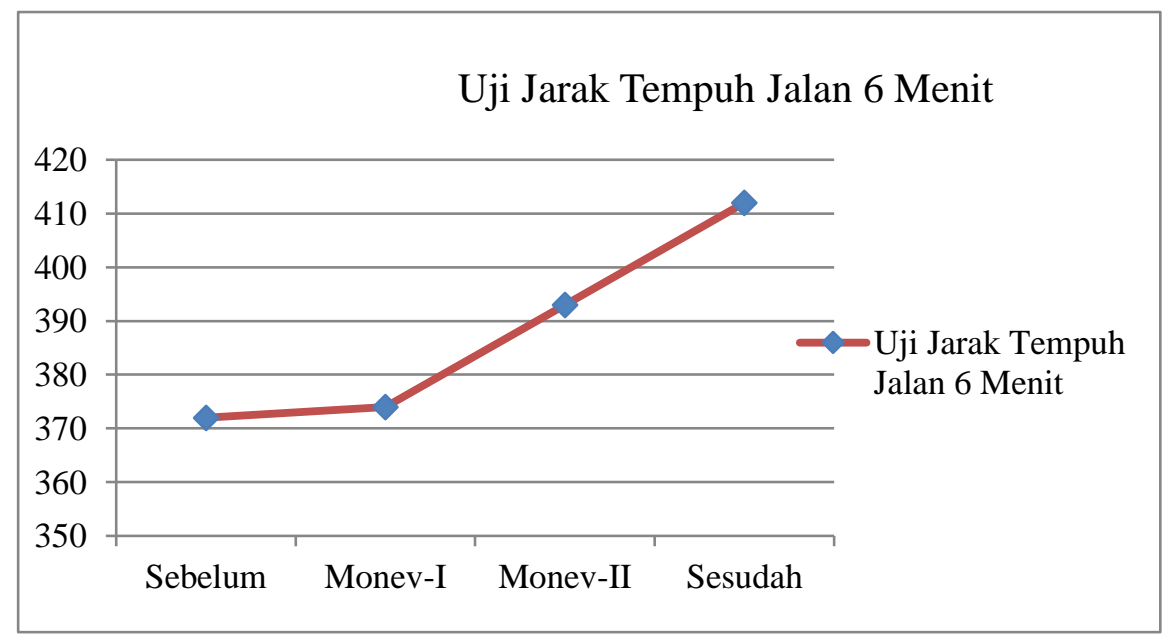

http://ejournal.urindo.ac.id/index.php/TI 
Bagan 5. Grafik Dinamika Perubahan Hasil Uji Jarak Tempuh Jalan 6 Menit

Hasil diperoleh 11 sampel mengalami peningkatan dari tingkat lemah ke tingkat kuat. Berdasarkan subjek penelitian didapatkan sebelum intervensi subjek yang memiliki hasil uji jarak tempuh 6 menit baik sebanyak 3 orang (20\%), Sesudah intervensi subjek yang memiliki jarak tempuh 6 menit baik sebanyak 11 orang $(26,7 \%)$. Hal ini sejalan dengan penelitian yang dilakukan oleh (Lain, 2007). Hal lain juga mengatakan bahwa jarak tempuh 6 menit meningkat dalam kelompok latihan dengan jarak dari 33 sampai $46 \mathrm{~m}$. Melihat hasil penelitian ini yang menunjukan bahwa hasil uji jarak tempuh 6 menit mengalami peningkatan setelah pemberian intervensi senam lansia dan refleksologi didapatkan hasil yang sangat signifikan. Hal ini sesuai dengan beberapa kajian teori yang menyebutkan bahwa daya tahan tubuh yang menurun menyebabkan akan mengganggu aktifitas fisik, kualitas hidup dan kerja fungsional paru dan jantung. Hal ini sejalan dengan hasil penelitian terdahulu yang menunjukan daya tahan kardiorespirasi adalah bagian mendasar dalam kehidupan seharihari pada pada orang tua
(Manfredini et al., 2016). Berdasarkan hasil uji pada data pemantauan sebelum intervensi dengan monev-I dan monev-I dengan monev-II menggunakan Paired T-test diperoleh hasil masing-masing $\quad \mathrm{p}^{1}=0,639 \quad$ dan $\mathrm{p}^{1}=0,040 \quad$ dimana hal ini menjelaskan bahwa terdapat perubahan pada pemantauan sebelum intervensi dengan monev-I namun, secara statistik perubahan ini tidak bermakna dikarenakan nilai $\mathrm{p}^{1}$ lebih besar dari 0,005. Sedangkan, monev-I dengan monev-II diperoleh nilai $\quad \mathrm{p}^{1}=0,040 \quad$ yang menggambarkan adanya perubahan pada sesi ini dengan hasil uji statistic yang bermakna. Dengan demikian penelitian yang dilakukan didapatkan hasil yang signifikan, hal ini searah dengan penelitian (Magistro, 2013).

Hasil Uji Wilcoxon , 11 subjek jarak tempuh 6 menit meningkat, 4 subjek jarak tempuh 6 menit menurun, dan 0 subjek tetap. Secara statistik menunjukkan perbedaan yang bermakna $\mathrm{p}=0,02$ ( $\mathrm{p}<0,05)$ sehingga $\mathrm{H}_{0}$ di tolak dan $\mathrm{H}_{\mathrm{a}}$ diterima hal ini menandakan adanya perubahan jarak tempuh 6 menit selama intervensi kombinasi terapi 5 Minggu. Hasil tersebut sejalan 
dengan beberapa penelitian dibawah ini terkait perubahan yang bermakna pada kardiorespirasi fiteness yang diukur dengan uji jarak tempuh berjalan 6 menit (6-MWD).

Mohamed, Serry, Elnahas \& Hakim., $2016^{56}$ menunjukan bahwa setelah 8 minggu dilakukannya intervensi, pada grup intervensi refleksologi menunjukan hasil yang signifikan pada penurunan tekanan darah sistolik dan diastolic sebesar $24.33 \%$ untuk sistolik dan $21.55 \%$ untuk diastolik. Kemudian hasil siginifikan pada penurunan serum kreatinin sebesar $12.82 \%$. Pada grup intervensi laser (grup B) menunjukan hasil yang signifikan pada penurunan tekanan darah sistolik dan diastolic sebesar $18.93 \%$ untuk sistolik dan $17.09 \%$ untuk diastolik. Kemudian intervensi laser tidak memberikan efek perubahan yang signifikan pada penurunan serum kreatinin, potassium, sodium dan calcium.

Korhan, Khorsid \& Uyar., $2014^{57}$ menyatakan ada perbedaan yang signifikan secara statistik antara rata-rata tekanan darah sistolik, tekanan darah diastolik, denyut jantung, dan nilai laju pernafasan pada kelompok eksperimen dan kelompok kontrol pada akhir refleksologi (30 menit) selama 5 hari. Temuan penelitian menunjukkan bahwa refleksologi adalah intervensi perawatan yang efektif dalam mengurangi tanda vital yang merupakan tanda fisiologis kecemasan dan juga mengurangi kebutuhan obat penenang pada pasien yang mendapat dukungan ventilasi mekanis.

Pada pulmonarary sistem respiratory, Polat \& Erguney., $20155^{59}$ menyatakan bahwa perbedaan antara dyspnea pada pretest-posttest dyspneu serta skor keletihan pasien pada kelompok refleksologi hasilnya signifikan secara statistik $(P<.01)$. Perbedaan antara pretest-posttest dyspneu dan skor keletihan pasien dalam kelompok kontrol secara statistik tidak signifikan ( $p>0,05)$. Kesimpulannya, telah ditentukan bahwa refleksologi mengurangi dyspnea dan kelelahan pada pasien PPOK.

Dan hal ini didukung oleh penelitian WU H.S. , WU S.C. , LIN J .G. dan LIN L.C., 2004 . $^{60} 44$ subjek di 
berikan refleksologi dengan titik pijat yang sesuai untuk pernafasan sedangkan yang lainnya di berikan pijatan pada titik refleksologi yang salah atau palsu. Kedua program akupresur tersebut terdiri dari lima sesi per minggu yang berlangsung selama 16 menit per sesi, diperpanjang selama 4 minggu dengan total 20 sesi. Sebelum refleksologi dimulai dan pada akhir sesi ke 20 , dilakukan pemeriksaan dengan instrument status fungsional pulmonary dan skala dyspneu yang dimodifikasi, skala kecemasan spielberger dan 6MWT dengan indikator fisiologis saturasi oksigen dan laju pernafasan yang diukur setiap habis sesi intervensi. Hasil dari penelitian tersebut menunjukan bahwa fungsi pulmonary, skor dyspneu, hasil pengukuran jarak berjalan 6 menit, skor skala kecemasan, dan indikator fisiologis kelompok akupresur secara signifikan membaik di bandingkan dengan kelompok yang diberikan pijatan pada titik yang salah. Temuan menunjukkan bahwa akupresur dapat digunakan sebagai intervensi keperawatan untuk memperbaiki dyspneu pada pasien COPD.

\begin{abstract}
Dengan ini peneliti berasumsi bahwa intervensi refleksologi dapat mempengaruhi peningkatan 6MWD, berdasarkan dari bukti-bukti ilmiah yang ditemukan, dimana refleksologi dapat meningkatan hemodinamik saat sesi, meningkatkan denyut jantung saat sesi, menurunkan tekanan darah, perbaikan dyspneu dan fungsi paru. Dimana itu semua merupakan peningkatan perbaikan yang di pengaruhi dari kinerja dan kebugaran kardiorespirasi.
\end{abstract}

$$
\text { Refleksologi mampu }
$$
meningkatkan dan memelihara sistem pernafasan dan jantung. Sehingga dapat memberikan dampak kesehatan yang baik, kemudian dapat membantu aktifitas sehari - hari. Dengan demikian intervensi senam lansia dan refleksologi secara garis besar dapat meningkatkan fungsional sistem pernafasan dan jantung. Oleh karena itu penelitian ini sejalan dengan (Hendro G S, 2014). Menurut (Hua et al., 2003) refleksologi juga mampu meningkatkan sistem pernafasan, meningkatkan fungsi kerja paru dan jantung, serta memberikan dampak kesehatan yang baik. 
Pada penelitian lain yang dilakukan oleh Fabio et al., (2016) juga mengatakan bahwa 6-minute walking test (6-MWT) meningkat dalam kelompok latihan dengan perbedaan jarak dari 33 sampai 46 m.

Dengan demikian, penelitian ini menggambarkan dinamika perubahan terhadapa hasil uji jarak tempuh (6MWD) pada lansia selama program senam lansia, namun terbatasnya literature menimbulkan pertanyaan pada penelitian ini yang diharapkan dapat dikaji lebih lanjut mengenai perubahan dari setiap periode yang semakin meningkat namun ada beberapa periode dengan perubahan yang tidak signifikan. Oleh karena itu faktor yang menyebabkan adanya peningkatan jarak tempuh 6 menit dalam kurun waktu 5 minggu dengan aktifitas sehari - hari yang dilakukan subjek di desa Puraseda. Dengan intervensi senam lansia dan refleksologi dan di ukur dengan jarak tempuh 6 menit secara signifikan mampu meningkatkan sistem pernafasan, mampu memelihara jantung, dan memberikan dampak kesehatan bagi lansia.
Setelah diidentifikasi, terdapat beberapa keterbatasan dalam penelitian ini, yaitu adanya aktivitas fisik yang dilakukan oleh lansia diluar kegiatan peneliti sehingga menyebabkan peningkatan dalam hasil jarak tempuh selama 6 menit sebelum dan sesudah intervensi senam lansia dan refleksologi.

\section{DAFTAR PUSTAKA}

1. WU H.S. , WU S.C. , LIN J .G. dan LIN L.C. (2004). Effectiveness of acupressure in improving dyspnoea in chronic obstructive pulmonary disease. Journal of Advanced Nursing 45(3), 252-25910.1002/rnj.266

2. G. Livingston, B. Blizard, dan A. Mann, 1993. Does sleep disturbance predict depression in elderly people? A study in inner London.

3. E Ernst. Is reflexology an effective intervention? A systematic review of randomised controlled trials. PMID: 19740047.

4. Ehrman Jonathan K., PhD; Brawner Clinton A., PhD; Mouaz H. Al- Mallah, MD; Qureshi Waqas T., MD; Michael J. Blaha, MD, MPH; Keteyian Steven J., PhD. (2017). Cardiorespiratory Fitness Change and Mortality Risk Among Black and White Patients: Henry Ford Exercise Testing (FIT) Project. The American 
Journal of Medicine 13977.

DOI:

10.1016/j.amjmed.2017.02

.03

5. Rômulo Araújo F., Edilson Serpeloni C., Enio R. Vaz R., Renata Selva tici Borges J., Analiza Mónica Silva, Cláudia Sofía Minderico, Paulo Manuel Rocha, Helena Santa- Clara, Fátima Baptista, Luis Bettencourt Sardinha, 2012. Cardiovascular fitness and cardiovascular risk factors among obese men and women aged 58 years and older, in Portugal.

6. World Health

Organization. " Library

Cataloguing-in-

Publication Data, report onageing and health".

ISBN 9789240694811

7. Rodero, S.R., J.L.F., Torre,

E.M., Calvanese,

V.,Fernandez, A.F., Fraga,

M.F. (2011). Aging Genetics and Aging. Aging and

disease Volume 2,Number 3; 186-195.

8. Faulkner, J.A., Larkin, L.M., Clafin, D.R., Brooks, S.V. (2007). Age-Related Changes In The Structure And function Of Skeletal Muscle. Clinical And Experimental Pharmacology And Physiology (2007) 34, 10911096.

9. .Abreu, S.S.E., Caldas, C.P. (2008). Gait speed, balance and age : a correlational study among elderly women with and without participant in a therapeutic exercise program.
Rev Bras Fisioter. 2008;12(4):324-30.

10. .Riskesdas (2013). Pokok Pokok Hasil Riskesdas. Badan Penelitian Kesehatan Kementrian RI. Diakses tanggal 4 Juli 2017.

11. Jones Jenny, BSc (Hons), RN, Thomson Patricia, $\mathrm{PhD}, \mathrm{MPH}, \mathrm{MA}, \mathrm{DipN}$, RN, RNT, Irvine Kathleen, BSc (Hons), Dip. Lib, Dip Ed. Tech, MCLIP, and Leslie Stephen J., BSc, $\mathrm{MB}$, ChB, FRCP, PhD. (2013). Is There a Specific Hemodynamic Effect in Reflexology? A Systematic Review of Randomized Controlled Trials. The Journal Of Alternative And Complementary Medicine Volume 19, Number 4, pp. 319-328. DOI: 10.1089/acm.2011.0854

12. Jones, Irvine, dan Leslie, 2013. Is There a Specific Hemodynamic Effect in Reflexology? A Systematic Review of Randomized Controlled Trials.

13. Widiyawati, W. (2015). Influence Of Elderly Gymnastics To Reduce Depression In 1. Kementrian Kesehatan Republik Indonesia (2016). Rencana Aksi Nasional Kesehatan Lanjut Usia Tahun 20162019. 
14. International Journal of Technology Enhancements And Emerging Engineering Research, 3(8), 90-94.World Health Organization (WHO) (2017). 16 Juli 2017.

15. Magistro Daniele, $\mathrm{PhD}$, Liubicich Monica Emma, PhD, Candela Filippo, $\mathrm{PhD}$, and Ciairano Silvia, PhD. (2012). Effect of Ecological Walking Training in Sedentary Elderly People: Act on Aging Study. The Gerontologist Vol. 54, No. 4, 611-623.

doi:10.1093/geront/gnt039...
16. Hendro, G S dan Ariyanti, Yusti. (2014). Materi ajar: Ilmu Pijat Pengobatan Refleksi. Jakarta. KKNI. 